\title{
From an Isolated State to a Migration Society - Transnationalism and Multilocality as Social Practise in Contemporary Albania ${ }^{1}$
}

\section{Daniel GöLER, Bamberg*}

with 3 figures in the text

\section{Content}

Summary

1 Introduction: Transition and migration in Albania .............................................138

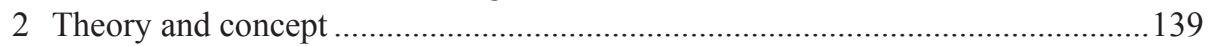

3 Phases and faces of post-Communist Albanian migration .....................................141

4 Long-term effects of migratory movements and transnationalism

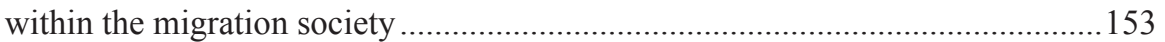

5 Migration and space - A transregional perspective? ……………………............. 154

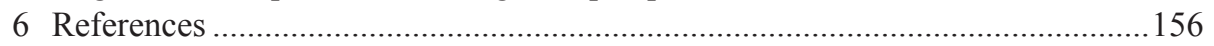

\section{Summary}

Present Albanian society is a migrant's society. In the Socialist era Albania was almost completely confined of international migration systems. Internal migratory movements were strictly controlled and regulated. That changed abruptly with the entry into the post-Socialist transition period. First spontaneous and hasty out-migrations have been followed by an unprecedented internal and international mass migration. Emigration, life in a foreign country and multi-local ways of life served as a kind of safety valve to overcome accumulated structural socio-economic deficits in the country and to reach individual needs. Living with all facets of migration is the social norm

$1 \quad$ The article was completed in December 2014.

* Daniel GöLER, PhD., Prof., Geographic Research on Migration and Transition, Institute of Geography, University of Bamberg, Am Kranen 1, D-96045 Bamberg; email: daniel.goeler@ uni-bamberg.de 
today. Almost half of the Albanian population has a personal international migration experience. Transnationality in the Albanian case is everyday social practise.

This paper shows the two and a half decades lasting way of Albania from the Communist 'isolated state' to a society that is heavily influenced by different forms and effects of international and transnational migration. Different periods of migratory movement and stages of national development as well as lines of continuity and change of a highly volatile migration system will be analysed on the basis of empirical findings. In order to strengthen the spatial issue in migration studies the suggestion is to broaden the concept of transnationalism by a new transregional perspective.

\section{Introduction: Transition and migration in Albania}

Emigration serves post-Communist Albanian society as a kind of safety valve for the manifold structural deficits inside the country. Hasty and spontaneous migrations herald a period of permanent emigration, connected with a massive loss of social, human and cultural capital and the bleeding of the country (among others: BARJABA \& King 2005; Vullnetari 2007, 2012, 2014; Göler 2009; Göler \& Doka 2014). The time span since the beginning of transition can be, also with regard to migration, divided into several phases. The phase of a first restructuring after the complete collapse of the Socialist state's economic and social systems in the early 1990s was rudely interrupted by the unrest of 1997. The Kosovo crisis did the rest, even though Albania was not directly affected. Then, after the turn of millennia, the Albanian economy experienced a period of dynamic growth. This was not to the least an effect of extreme external migration, when another 481,000 Albanians emigrated between 2001 and 2011 (INSTAT 2014b, p. 9). The capital inflow sent by migrants was an important driver of that dynamic. Remittances and migrants' savings secured countless families to survive in difficult times. Besides into daily livelihood, they were often invested in real estate or business activities.

Then, beginning in 2008, the global financial and economic crisis seemed to run past Albania, due to the countries' still weak inclusion into international capital and trade flows. Soon, however, Albanian migrants were affected by economic problems in their main destination countries, namely Greece and Italy, where around $90 \%$ of Albanian migrants used to live. In this respect, Albania was indirectly affected by an externally caused crisis again. Since then, a period of increasing return is emerging. This, however, takes place under problematic circumstances and leads to the crucial question, whether migration and return still define an economic resource in Albania.

In the following, main characteristics and trends of migration as well as their consequences and effects will be outlined for each phase. 
The analysis of scales, relationships between immigration and emigration and the role of choice and coercion in decision-making by migrants is, following DüvELL (2009, p. 342), based on own empirical findings, which are the outcome of a long-term and intensive study of the country's general socio-economic and political transition. A comparison with information from statistics and other literature helps to gain reliable findings on interruptions, changes and varieties of the Albanian migration system. The aim of the contribution is to point out singularities as well as similarities of a highly volatile, liquid, fluid and elusive migration system and to discuss findings in a comparative perspective. A certain emphasis is set on the current wave of return migration, since it is necessary to study that phenomenon also against the background of recent history.

\section{Theory and concept}

The findings on the Albanian migration society are analysed and interpreted in the light of transnationalism (cf. Glick Schiller et al. 1992; Khagram \& LevitT 2008; Vertovec 2009). Transnationalism is understood as "increasing interconnections between nation-states across borders" with "political, economic, social and cultural dimensions" (FAIST et al. 2013, p. viii). Main outcomes of transnationalism from the geographical point of view are the various effects of (international) migration. Among them are intensive spatial and social interlinkages, e.g. flows of capital, mutual communication and advocacy or transfers of innovation etc. Each is based on activities by migrants. From this perspective, the transnational social space can be seen as an arena of social interactions (DAHINDEN 2009, p. 16; PRIES 1999).

This is a suitable theoretical and methodological framework for the analysis of Albanian migration (to some extent in the sense of KING 2005), because the widespread Albanian diaspora regularly maintains close contacts not only within the ethnic communities in the host societies, but also to the country of origin. Multilocality, circular mobility and dense communication networks come as a matter of course for Albanian migrants. Maybe this was mainly a part of the survival strategy of individuals, households, and families in difficult times of early transition. Furthermore, this strategy consolidated as a common means of social resilience for a highly vulnerable population. Therefore, migration and transnationalism is part of "risk diversification" (Williams \& BALÁŽ 2015, p. 99). Corresponding family and migrant networks have long since replaced the government social security systems.

This leads to the paradigm of the so-called migration-development-nexus (for example Nyberg-Sørensen et al. 2002) - the question how far economic development is related to migration (HAAs 2010). Over a long period both migration and development have been assessed separately. Not before the transnationalism debate it became quite 
obvious that they are linked in many ways. Research set the lens on the possibilities for a valorisation of long-distant, migrant-based interconnections in terms of development not only for the global North but also for the South (CASTLES \& MiLler 2009, pp. $57 \mathrm{ff}$.). Politics saw an appropriate tool to fight spatial inequality.

Migration research offers different assessments on the material and immaterial repercussions of migration on sending countries. Some see migration and remittances as a "new-development mantra" (KAPUR 2004). Others estimate the possible economic effect given by migration as "hyperoptimism" (FAIST 2008). For a certain period, most scholars pointed out a kind of win-win-situation between sending and receiving countries defined by emigration, remittances, and return. Since the beginning of the global financial and economic crisis, estimation turned into a "new migration-and-development pessimism" (GAMLEN 2014). Against this backdrop, the analysis of Albanian return migration is a good opportunity to stress the positivistic migration-development-nexus in the light of economic downturn and a changing migration system. This may lead consequently to a slightly critical attempt towards transnationalism and development (see also GLICK SCHILLER \& FAIST 2010), questioning stability, sustainability, resilience and resistance of migratory-based livelihoods. Further discussion on the migrationdevelopment-optimism or -pessimism is a necessity. I will revisit the debate by the end of the paper.

The empirical basis was collected during several cooperation projects in Southeastern Europe or Albania, respectively. The studies' methods represent a wide range of quantitative and qualitative approaches. The first reported project on migration and depopulation in Albania in 2004 (see Section 3.1) represented a quantitative survey. A second one on migrant's entrepreneurship (Section 3.2) switched to qualitative methods by conducting semi-structured interviews with guidelines and biographical elements in 2006. The findings on return migration from 2012 (Section 3.3) followed an explicit qualitative-narrative approach using elements of "multi-sited ethnography" (MARCus 1995). Basic information was gained by modelling individual lifelines in the form of migration biographies, a procedure, which was, among others, applied successfully by KING et al. (2008, p. 44). Migration trajectories show the (possible) variety of migration processes behind a way from A to B including both internal and international steps of migratory movements, or, in the words of KING \& SKELDON (2010, p. 1622), by "linking and sequencing" migration pathways. Similarly, HAAs (2008, p. 31) focused on families or households as basic units for analyses. Such household trajectories show the whole complexity of migration and have been used as another helpful approach for the study on hand. 


\section{Phases and faces of post-Communist Albanian migration}

\subsection{Mass migration of the 1990s and the depopulation of the periphery}

Albanian migration is often perceived as emigration. What had begun as a sometimes spectacular escape from the "isolated state" - for example in the case of the embassy refugees who risked their lives in 1990, when a truck broke through the demarcation fence onto the territory of the German Embassy in Tirana - thickened in the following period in a kind of mass exodus. Until the end of the 1990s, around 500,000 Albanians (mostly from southern Albania) emigrated just to Greece and another 200,000 (mainly from central and northern Albania) to Italy. The total amount of emigrants is estimated at 750,000 Albanians, equivalent to a quarter of the whole population (VULLNETARI 2007, p. 36; estimates by BARJABA 2000).

At the beginning, emigrants were mainly young, male, willing to take a risk and sometimes just adventure-seekers. Almost every family had sent one or more members to work abroad. As already mentioned, this is a part of the survival strategy and thus a means of social resilience. The consequences of the ongoing emigration on the population structure, in addition to pure population decline, have been dramatic. This manifested itself in deformed age-'pyramids' with concave flanks in the age group of young (male) working-age classes (INSTAT 2009, p. 8), a typical characteristic of societies with strong emigration. More than $70 \%$ of all migrants were of working age; $85 \%$ of migrants to Italy were between 20 and 45 years old (GJONCA 2002, p. 21).

The associated brain drain can hardly be overestimated. Albania lost in the first half of the 1990s around 35\% of high-skilled workforce (1991-1995; GJONCA 2002, p. 19) and subsequently a third of academic teaching staff (SCHмIDT 2003, pp. 16f.). Depopulation and sometimes complete abandonment of settlements in the periphery of the country is one of the most evident consequences. In the district of Tropojë for example, reported between 1995 and 2002, all municipalities (with just one exception) have been characterised by depopulation, often in existential dimensions (Fig. 1). A number of mono-structured mining settlements in peripheral areas or countless villages in the mountains have been partially or totally abandoned (GöLER 2005, p. 61).

Processes like the depopulation of the periphery are a result of international, but also of internal migrations. In the shadow of massive emigration, it should not be overlooked that during the inter-census period between 1989 and 2001 more than $50 \%$ of the population had changed their residence within the country. Thus, internal migratory movements represent a very significant and rather underrated part of post-

2 LichtenBerger (1976) called Albania an "isolated state". 
Figure 1: Change of population number in the Tropojë District 1995-2002 (Source: Municipality of Bajram Curri)

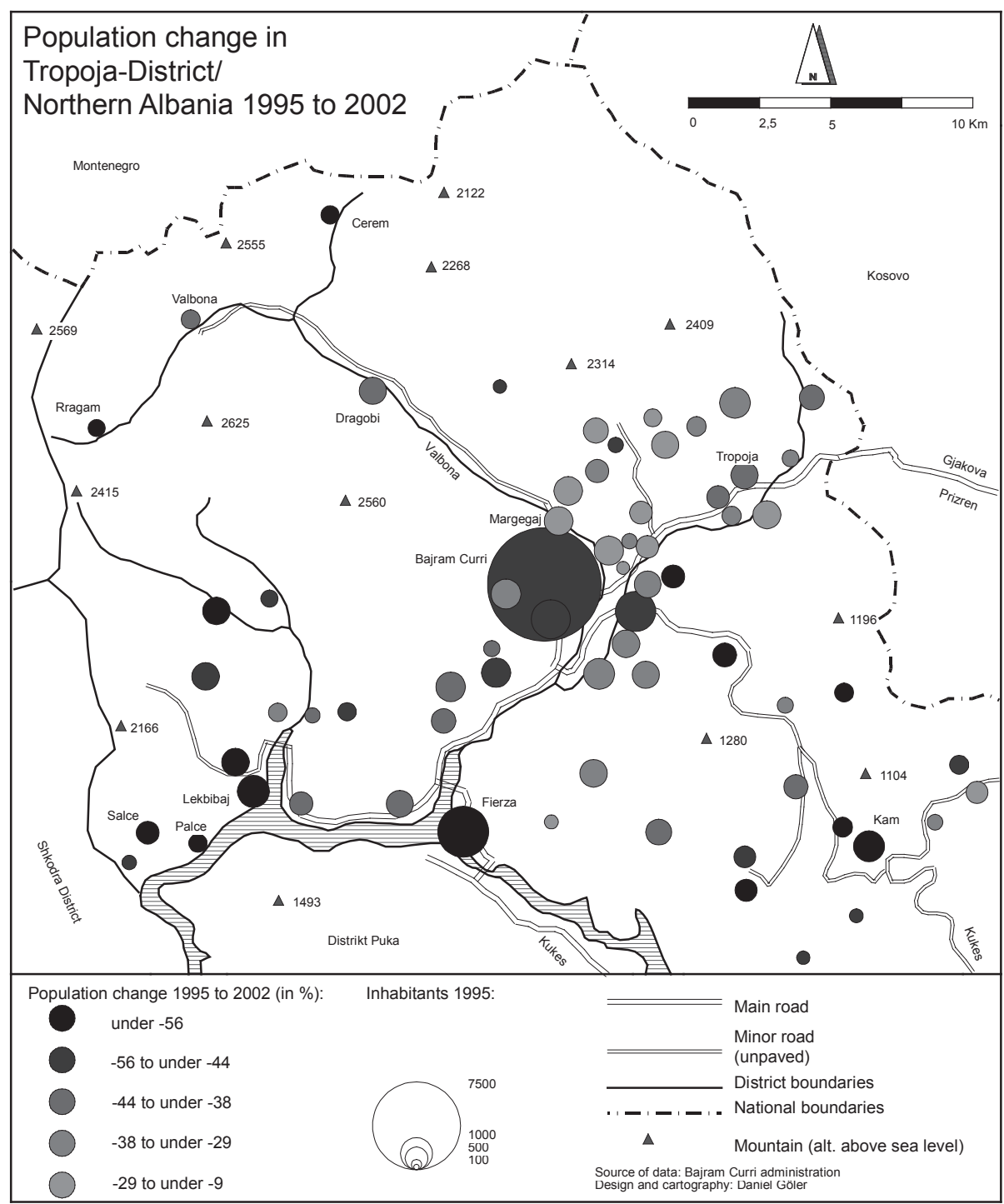

Socialist mobility, especially with regard to spatial differentiation inside the country. And they are (another part of theoretical reflection by the end of the paper) closely interconnected with international migration to and from Albania. 
Our survey in the north-Albanian districts of Tropojë, Kukës, Pukë and Dibrë in October $2004^{3}$ resulted in high migration potentials (GöLER 2005, p. 98). About half of the residents still living there - in the case of Tropojë even 58\% - declared themselves as "mobile", which means that they are ready to out-migrate more or less promptly. In this respect, ongoing depopulation of the periphery was already foreseeable at the time. This seems hardly surprising given the low level of living conditions there (low Human Development Index, income and employment; poor infrastructure, lack of perspective; see for example VulLnETARI \& KING 2008). Relevant from a spatial perspective is a multi-determined bifurcation of family life, stating that the parent generation relocates in lower Albania (preferably in the Greater Tirana Agglomeration) - with the option to migrate or maybe circulate from there to a foreign country. The descendants seek their perspective in university studies or employment abroad, while the elderly (grandparent) generation remains in the periphery.

However, in most family constellations different forms of migration and sending remittances play a certain and often prominent role. In many cases, the inflow of capital led to cropland abandonment (MüLLER \& MunRoe 2008) and created a kind of 'rent seeking mentality', when people relied on the money from abroad and abandoned working on the fields at the same time. Another part of remittances is used to keep the social status, maybe by organising big family events or just by building a house.

The personal and spatial arrangements indicate a strong relevance of regional subsystems in the framework of transnational constellations. This was recently defined as "trans-regionalism" to be more precise in these terms (GöLER \& KRISJANE 2013). Such socio-spatial arrangements and assemblages with elements of internal and international migration and family multilocality often served as a starting point of entrepreneurial activities at home (migrants' business).

\subsection{Returnee's business in good times}

Remittances are not only an important factor of day-to-day survival but also a promoting factor for the formation of private entrepreneurship in Southeast Europe (KILIC et al. 2009). Studies based on entrepreneurs' biographies showed that private financial transfers from abroad play a crucial part in the foundation of small and medium-sized enterprises (GÖLER 2007). Private entrepreneurship run by return migrants (returnee's business) is one of the main characteristic elements of the nexus between migration and development. The determinism of entrepreneurship and migration is a rule in Albania:

3 Standardised survey with face-to-face interviews with 506 respondents, conducted in October 2004 in the districts of Tropojë, Kukës, Pukë and Dibrë as part of a cooperation project in the framework of the "Geographical teaching and research network on South-East Europe" with participants from the geographical departments of the universities Bamberg and Tirana on "European Shrinking Regions", funded by the German Academic Exchange Service DAAD (see GöLER et al. 2005). 
Only one out of 34 entrepreneurs in the Albanian sample of our survey ${ }^{4}$ was not in emigration before the start-up. In fact, those start-ups usually are prepared with a stay of up to ten years abroad, mostly in Italy or Greece. Two examples may illustrate the broad variety in entrepreneurial biographies, their backgrounds and framing contexts as well as the role of spontaneity and coincidences:

The individual biography of one out of three owners of a medium-sized company in Vlorë (southern Albania), specialised in the production of furniture, is a sequence of back-andforth movements, which are strongly connected with several personal ups and downs. Initially, our interviewee gained a university diploma in engineering and was employed in oil drilling in the late Socialist period. Being unemployed after the fall of the Communist system he started, like many others, running a kiosk and selling some fruit and small goods, then enlarged to import of food and, later on, of wooden chipboards. In 1997, he started a bigger shop, but wasn't successful. So, 1999 he re-started import-exportactivities, mainly with spare parts for furniture. In between all these different activities the interviewee reported several temporary limited stages abroad in different countries (Italy, Spain, Dubai ...), mostly being employed in construction. Back in Albania, he invested 2003 in the start-up of the company.

The products (furniture for kitchen) were designed by the help of an online tool, which is available on the internet-homepage of a well-known German company. Such a procedure is widespread in Albania: Another company in the neighbourhood buys high quality designer sofas in Italy, dismantles them and reproduces a certain number of them more or less faithful later on. Maybe the most surprising and atypical fact in our example is that the owners took money from a bank credit to invest in modern production facilities (GöLER 2011). The company still existed in 2012 (when we repeated our visit), so we assume a certain success of the former start-up.

The second example seems to represent a more straightforward biography, but comprises also a stake of resourcefulness and flexibility:

The owner of a company, which produces building materials in southern Albania, went into early exile at the beginning of the 1990s. He spent almost ten years working in northern Italy in a large company for building materials as driver of the head of the company. This means that he got by observation some knowledge concerning the whole branch, but never gained practical experience in the production process. Nevertheless, he used his own intuition on production and organisational processes and routines and established a medium-sized production site with the same portfolio after return to Albania in $2002 / 2003$. He took the opportunity to buy necessary technical equipment used, but for low price, from his former employer. This was undoubtedly helpful, as well as the continuation and development of business relations to that Italian company.

Both examples are living representatives for the strong interconnection of migration and development. These entrepreneurs - just two among others - invested

$4 \quad$ Qualitative survey with semi-structured in-depth interviews with narrative elements of a total of 34 companies and entrepreneurs in July 2006 in the framework of a DAAD-project in cooperation together with the geographical departments of the universities Belgrade [Beograd] and Tirana. 
financial capital, gained by employment abroad, after return. They valorised knowhow and technology for their start-up in extremely dynamic branches with quite simple ways of production of goods that have been imported to Albania so far. At the same time, they provide a certain number of jobs there.

To sum up, some key findings from these studies on migrant-based and more or less successful entrepreneurial start-up activities ${ }^{5}$ in the manufacturing sector during the 2000-decade should be fixed. At first, there is a striking gap between formal vocational qualification or practical experience, which was gained abroad by the entrepreneurs, and the branch in which a start-up is taking place. Products and production methods rely mainly on reproduction and hardly on innovation. Second, investments are made almost exclusively in self-employment; capital investments, however, are extremely rare, especially outside the own family network. Consequently, most of the companies are small and keep focused on the local or regional market. Arising structures are limited and not competitive on international markets. Third, under the favourable conditions for entrepreneurs in the first decade of the $21^{\text {st }}$ century the common practice of trial and error often leads to successful, but sometimes suboptimal results.

However, beside this deficit-oriented evaluation that marked several critical points concerning entrepreneurship of the 1990s and 2000s it should be noted that migration in the Albanian case must be seen as a resource in the sense of the migrationdevelopment-nexus, at least in the 'good times'. But the general framework and the preconditions of migration and return have changed fundamentally by the end of the decade.

\subsection{Return in times of crisis}

The global financial and economic crisis meant a dramatic break not only for the countries in Mediterranean Europe, but also for migrants from Albania. Countries that had been the main destinations of out-migration from Albania like Italy and especially Greece were heavily affected. In 2011, around 450,000 Albanians used to live in Italy and another 500,000 in Greece (INSTAT 2014, p. 36). The number in Greece would increase to 677,000 (ibid), if the ethnic Albanians with Greek citizenship and those who are born there as second generation including the naturalised would be counted in addition. In contrast, the number of about 25,000 returnees annually in the years 2010 and 2011 - almost 95\% of them from Greece and Italy - appears quite low

5 It is one of the basic methodological problems of empirical research on business foundation that the findings concern usually those companies that are resistant to the market and thus exemplify the most successful. However, failed start-ups would be at least of the same interest in terms of a comprehensive problematisation. But failed entrepreneurs are hard to find for such a study and are usually not that open for a personal interview. 
(INSTAT 2014b, p. 39), even in reality it is likely to be somewhat higher. ${ }^{6}$ And it should not be overlooked that net migration is still negative (minus 50,000 persons in 2012). This means that emigration is declining, but still persistent; just the volume of return migration increased. This is certainly not a reversal of the trend. However, if immigration by return should stabilise at the current level (as it looks like), then the migration system and the migration society of Albania will face dramatic changes and challenges.

It is remarkable that - after the emigration of the 1990s was heavily maledominated - recently almost half of the emigrants are female. Transformed gender division is due to student emigration as well as to family reunification (women follow the men abroad); the latter may be interpreted as a perpetuation of life in the diaspora. Anyway, with about a quarter of all return migrants, women are the minority among them (INSTAT 2014b, p. 30).

In the third decade of post-Socialist transition, the whole range of phenomena of a migration society like emigration, return migration, circular migration, transnationalism and multi-locality should be re-evaluated due to a diametrically changed framework of action. So far, return was an option with corresponding degrees of freedom. Faster than expected, it turned into a dead end with serious constraints.

The review of a study of the think tank ACIT (Tirana) on return migration led in media in October 2012 to the headline "Greek crisis as Social Bomb for Albania" (Tirana Times Oct. 5-11, 2012, p. 7). And indeed, it is a central issue in geographic research on migration, how migrants and the Albanian migration society deal with the new situation including novel opportunities and problems that may result from the constraints arising. Can return migration in the Greek-Albanian context under the present conditions still be seen as resource like it was the case a few years earlier (see Section 3.2)? Or do return migration and the necessity of re-integration define a new bundle of problems? Such questions have been investigated in October 2012 as part of a case study in southern Albania, the main region of origin and currently a frequent destination of returnees from Greece. Nowadays, the long-lasting high rates of emigration to Greece turned into a problem from a completely different perspective. ${ }^{7}$ Beside aspects of migrants' entrepreneurship, which have been designed as comparative studies to our preliminary ones, issues of education and vocational training, school and

\footnotetext{
$6 \quad$ These are only officially registered return migrants. Real figures should be much higher, partially due to a certain number of unreported cases. Another problem is the definite return of temporary or circular migrants: For example, multi-local acting families giving up their Greek place of living are, in the statistical sense, not included as repatriates. However, ACIT speaks of 180,000 returnees within five years (2008-2012) alone from Greece.

740 biographical interviews have been conducted with returnees and relevant institutions in the south-Albanian regions of Himarë, Korçë and Gjirokastër in October 2012 in the course of a study project of the Geographical Research and Teaching Network SEE with participants from Albania, Germany and Kosovo (universities of Bamberg, Tirana and Prishtinë/Priština), which was kindly supported by the DAAD. The fieldwork was sustained by media analysis and data from official statistics.
} 
the integration of the young or second generation as well as impacts on family lives have been on the agenda of empirical interest.

\section{Heterogeneity of the group}

Painting a consistent picture of the returnees, on their characteristics, individual backgrounds, decision-making etc. is hardly possible. In statistical average, returnees spent 6.2 years abroad. Albanians in Greece - where over $70 \%$ of returnees come from - lived even seven years there (INSTAT 2014b, p. 31). However, the range seems to be wide: Our survey included people with only a short stay abroad (especially young people) as well as others with a residence time of 15 up to 20 and even more years abroad.

In general, returnees are of all ages. The average age is 38 and the median age 35 years. The majority tend to be younger age groups, which is related to the problem of youth unemployment in Greece. Another indicator for determinism of return by the Greek labour market is also the fact that nearly three quarters of the returnees are male (INSTAT 2014b, p. 30). This is of course a result of the male dominance of the total emigration so far and explains to a certain extent the low proportion of female returnees at the same time. But it is also related to the labour market segments in which Albanian migrants usually are employed. Branches such as construction, handicrafts as well as the service sector and agriculture (IOSIFIDES 1997) are mostly affected by the crisis. Alltogether, this is emphasising the coercive character of migration. On the other hand, the elderly generation of 60 plus represents less than $10 \%$ of returnees, which is partially also a statistical effect, because there are only few potential migrants that may have reached that age already (i.e. the very early emigrants from Albania). However, current return migration does, in contrast to return in other contexts, not correspond to mostly voluntary "return of retirement" (CERASE 1974).

\section{Time and space, motivation and destination}

When the economic downturn and, as a consequence, a possibly forced return became apparent in 2009/2010, an attitude of 'wait and see' was prevalent among Albanians living abroad. Many decided the question "Should I stay or should I go" (GöLER \& DoKa 2014) with sedentarism, which means that they just remained in Greece as long as possible. Such considerations usually relate to the cost of living on the one hand and, on the other, to the family situation. After all, nearly two-thirds of the returnees are married or family-bound (INSTAT 2014b, p. 30). A major role play children that are still going to school: as a rule the school examination should be made possible for them in familiar surroundings. At the same time, notwithstanding the upcoming crisis, increasing remittances of Albanians indicated intensive activities 
to prepare themselves for return. Aside that, high amounts of money were transferred from Greece to Albania just to secure saving them from the ailing Greek banking system.

Statistics from 2001 until 2011 confirm the acceleration of the Albanian return migration from Greece, which tends to continue in 2012 to 2014 (Fig. 2). These returns, decided under intense economic pressure, are expected to grow considerably in the near future. Seasonal labour migration to Greece, which has long been also a means for Albanians to bridge periods of economic problems, will decrease at a similar amount.

Figure 2: Number of return migrants to Albania 2001-2011 (Source: INSTAT 2014b, p. 39)

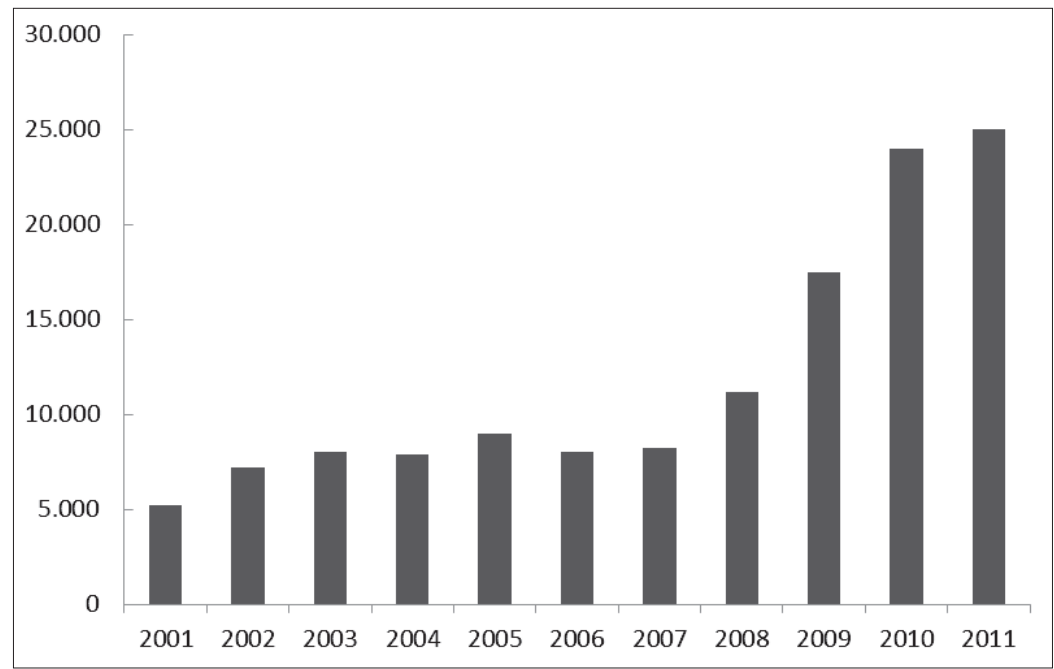

Main countries of origin of returnees are, as already mentioned, by far Greece $(70.8 \%)$ and Italy (23.7\%). Those who have arrived permanently in the United Kingdom, Germany or the USA will remain there even in potentially difficult times. The main reason for the return is unemployment (88\%, INSTAT 2014b). Other motivations such as missing documents or explicit plans to become an entrepreneur in Albania are subordinate.

The majority of the returnees return to the place of birth or a previous place of residence, which was retained during absence; property of real estate plays an important role. Actually only about $10 \%$ of the returnees change their place of residence in Albania during return (in comparison to the place they left while emigrating).

The imbalance of residence before emigration and after return show the biggest positive difference in the case of Tirana; the likelihood of return is also higher in other low-Albanian and coastal regions like Durrës, Lezhë or Vlorë (INSTAT 2014b, p. 33). 
The opposite is true in the peripheral or mountainous regions, which are for returnees due to poor living conditions significantly less attractive. This spatial distribution - the change of residence during the cycle of migration and return - corresponds exactly to the pattern of internal migration (see Chapter 3.1). To sum up, return augments the long-term manifested regional disparities.

\section{Education and vocational training vs. professional experience and personal skills}

Brain waste, i.e. the (in comparison to education) under-qualified employment, is a rule in Albania. It is one of the central problems of the labour market and another essential motivation for emigration. However, Albanians in the diaspora also experience discrepancies between formal education and qualification levels and - in particular in Greece - the professional position there. We find only very rare examples that Albanians are employed abroad due to a formal qualification; as rare it is that formal qualifications acquired in Greece prove to be useful after returning to Albania. Most migrants there were or are still employed as unskilled labour force. So did a specialist with a university degree in agricultural sciences, nearly 50 years old, living close to Gjirokastër:

The interviewee, who was born as member of the Greek minority in a village close to Gjirokastër, acquired a university degree in Korçë shortly before the state collapse in 1991. Multiple shorter stays in Greece followed. The riots in 1997 - they have been acute especially in southern Albania - were the catalyst for permanent emigration. In his first years, he worked with a temporary contract in research in the field of microbiology, more or less equivalent to his academic education. Then he was employed occasionally in agriculture and in construction, followed by a permanent employment as unskilled worker assembling electronic devices in Athens [Athina]. After return in 2011 he opened a shop for agricultural products (fertilizers, chemicals, seeds, mechanics), obviously based on his knowledge of agricultural needs.

Aside several breaks in the professional biography, also lines of continuity exist. As it is usually among Albanian migrants, the whole human and social potential and capital may have been recombined and valorised during the migration biography. The return is, due to the economic problems in Greece, considered as permanent; repeated emigration is an option just in the case of business failure.

The individual migration pattern of this interviewee is a very typical one: a period of backand-forth-migration during the 1990s was followed by a longer permanent stay abroad in the 2000s and return to Albania recently.

It is quite opposite in the case of special personal skills that have been adopted by 'training on the job'. Sometimes these activities may serve as key to employment after return. A certain number of examples, among them a car mechatronic in Gjirokastër, 
may underline this. In general, the demand for qualified employees is quite limited in Albania. Therefore, migration-based knowledge from abroad is much more likely to serve as a springboard to self-employment, at least in a similar way as it was already reported in detail (Section 3.2). In most cases these start-ups focus on the servicesector - handicraft, food, tourism, all business that require only a little amount of investment - and less on the second sector. The degree of 'preparedness' is critical and decisive for success or failure (see also CASSARINo 2004, pp. 271f.). Two contrasting examples may illustrate this:

The first example is a female person at the age of 34 years at the time of the survey, who was born in Gjirokastër (southern Albania). She emigrated at the age of 13 years in the context of a tied migration (a family migration together with the parents) to Greece. She graduated from vocational training in graphic design and worked in a media agency. Return was not included in her plans, not at least she had spent more than half of her life outside of Albania. In fact, she felt well-integrated in Greece. With the upcoming crisis there, unemployment was predictable for her sooner or later. Insofar she anticipated unemployment by returning to Gjirokastër - not without being carefully prepared for that step by using her acquired expertise: In the month before her return she installed and opened, together with a local business partner, a shop for gifts and souvenirs in the old town of Gjirokastër, which is classified as a UNESCO-world heritage. So she already created for herself a 'second leg' before return. Vocational training, professional experience, the long-term preparation, adequate planning and conception are, in this case, decisive factors for this, despite the problematic framework conditions, seemingly quite successful remigrant business.

Less reflected seems the second example, the return of a 41-year-old man in his native village in Delvinë (southern Albania). He had left this district to Greece 20 years ago. As a trained cook with primary-school graduation he hired in various jobs: two years in construction, then in bakeries - at the beginning as driver, later on he switched to production. Multiple attempts to become self-employed with a bakery in Greece failed. Finally, the job loss of his wife and his only low wages were crucial for the return to his home village in early 2012. There, opening of a bakery seemed to be a good idea as the family owned a plot there. These are in itself quite good preconditions, only the location in a small village in the countryside is rather uncritically chosen as the demand is low, because families are used to bake bread by themselves. The future of the company and its founder is unstable because the savings were depleted with the start-up. However, a "second return" (CARLING \& ERdal 2014, p. 6) to Greece is conceivable, but hardly feasible in the current individual situation and under the general economic conditions.

In contrast to returnees business in good times (Section 3.2) we found a number of problematic examples in the recent survey, even if it cannot be derived with quantitatively significant empirical evidence. But there is no doubt that the framework conditions for start-ups in Albania became harder. The same is true for the situation on the labour market (especially for returnees) since the beginning of the crisis, due to more competitors and more competition. 


\section{Social aspects of re-integration}

All migrants are affected by the social dimension of return, namely the question of re-integration. Re-integration in this context is a fuzzy concept when we talk, for example, about foreign-born descendants of migrants or those, who emigrated in young age tied with the family. Maybe these groups are the most problematic ones in these terms. Albanian emigrant families usually have maintained close contacts inside the diaspora as well as to the homeland, e.g. by regular visits, family celebrations or even holidays. However, as the aim of most migrants was a high degree of integration and sometimes maybe even assimilation into the host society, Greek language was spoken in many families - at the latest when children started to attend school there. Most of the descendants are not used to speak Albanian, because they never learned it systematically. Changing to an Albanian school after return is particularly difficult and sometimes impossible for them, less due to formal, but rather due to linguistic reasons.

Information on the problem of youth return mobility is still vague. According to media reports, by the end of 2012 around 260 school children shall be returned to Gjirokastër, for example (GöLER 2014, p. 29). The State Office of Education in Korçë, a city with a population of about 50,000 inhabitants with traditional intensive emigration and, since a couple of years, a sharp decline in population growth, provides informative figures: the number of recognition of foreign school certificates amounted before 2010 at 20 to 30 per year, in 2010 they were already 165, the following year 221 and in 2012 (until October) already 235 - 232 out of them from Greece, 2 from Italy and one from the United States. In addition, the number of pupils incoming to classes during the school year is increasing, which indicates an increase of economically forced migration. This inflow causes considerable frictions in schools, because existing capacities were diminished significantly over the last years due to declining fertility and emigration. Schools are, as the pupils are, not prepared for such a demand.

As a consequence, Greek schools in southern Albania still are popular. They were founded in post-Socialism as private schools mostly in southern Albania and financially supported by the Greek state, mainly to maintain language and culture of the Greek minority there. Most of the school attendance in previous years aimed - as it was reported in Himarë - on the preparation of emigration. Recently, these schools serve to facilitate re-integration. However, the financing by Greek authorities is eroding, so the fees had to be raised. This is far beyond the means of most returnees. As a consequence, the majority of returnees' children have to turn to state schools.

In general, language and socialisation is an essential social-psychological problem for many young people. Phrases such as "I cannot express myself in Albanian language" or "I'm not feeling Albanian, I feel Greek" are quite common in interviews with young returnees, sometimes they are even in the parental generation. It is comprehensible that these youngsters see their future not in Albania; just 'returned' they wish to emigrate, 
but instead of neighbouring countries now to Central and Western Europe or just overseas. And they want to emigrate as soon as possible, again seemingly spontaneous and maybe not well-reflected enough. ${ }^{8}$

\section{Family bifurcation}

The phenomenon of family bifurcation as part of personal vulnerability in the context of return is dependent on the position in the family or life cycle, respectively. In the case of early returnees, i.e. those prior to 2008 , this is less a problem. They usually had chosen the time of return voluntarily and were prepared accordingly. Under the conditions of economic downturn and manifold constraints (loss of job and income, rising living costs, general uncertainty) that is different, especially when return is for economic reasons not variable in time and has to be carried out in a biographically unfavourable situation. The search for employment and income is often enough a reason to split the family, not only during emigration but also when returning. Such a "split return" (CARLING \& ERDAL 2014, p. 6) as another spatial division of the family has been reported often:

A returnee to a village close to Himarë is even an example of a 'reverse split'. He might illustrate the reversal of migration-related family bifurcation. He went at first, as it was common at the beginning of the 1990s, as head of the family alone to Greece. His wife and child followed after he had found a job. The family - they even increased by a now 10-year-old daughter - can be regarded as established and well-integrated there. The son gained a university degree. They own a flat in Athens. With regard to career progression, the man changed his professional position after twelve years. Eight more years later, in 2011, he accepted the compensation offered and returned alone to Albania. The son in turn is already working and remains in Greece. The wife is still working as a waitress, but the conditions are getting worse due to several wage cuts. The only argument to stay is the daughter, who was born in Greece, is still attending school and speaks only little Albanian. The family would like to enable her to finish the high school graduation and to offer her a future perspective abroad. The returnee himself, now in the midst of his 50s, runs a smallscale agriculture (livestock, beekeeping, olive trees) on his property near Himarë, like his ancestors did and like he did before emigration. "With agriculture", so the almost fatalistic remark by the end of the interview, "you've always something to eat and might do your livelihood, even if the crisis gets worse."

Such a split return can be observed quite often among elderly migrants. For those who return to Albania it is a return to still familiar surroundings. For young people,

8 Thus, the number of asylum applications from Albanian citizens has increased between 2014 and the end of January 2015, almost at the same extent as those from Kosovo, although there is nearly no chance for recognition. (Press release of the German Ministry for Internal Affairs, Feb. 9, 2015; see docs.dpaq.de/8533-090215_25_042_asylantr_ge_im_januar_2015. doc) 
however, it is the emigration to a more or less foreign country that cannot provide them any viable and attractive perspective. In this respect, they are looking for their future in other contexts with better opportunities. Staying in Albania is then at best an interlude of a broader migration biography. Others have chosen this path directly, by emigrating from Greece directly to a third country, so they have not even 'returned'. Again, the minority has a certain impact, because having a Greek passport gives access to the EU labour market.

\section{Long-term effects of migratory movements and transnationalism within the migration society}

As a result of the analysis of two and a half decades of recent Albanian migration history, a number of characteristics and consequences of post-Communist mobility can be clearly outlined. Massive emigration had both positive and negative consequences for Albania. The same seems to be true for current return migration. So, similar phenomena - emigration, return migration, circular migration, transnationalism and multilocality - have been reassessed against the backdrop of a certain limitation of available options concerning the individual migration decision in the current third decade of Albania's transition.

The country's socio-economic backwardness existed for a longer period. But with the end of the Socialist system it became visible to everyone. Further economic marginalisation and destabilisation of living conditions during the transition period served as a stimulus for the migration of a highly vulnerable population. Migration was an important part of individual surviving and development strategies and, to some extent, an economic safety valve. Migration trajectories show a pattern with voluntary and forced emigration and return, both combined with several intermediate forms of circularity and oscillating mobility. Consequently, there is a strong interrelation between internal and international migration. To sum up, return was and is a permanent option in Albania at any time. As a result of the post-Socialist mobilisation, the stock of emigrants today is $45.4 \%$ of the total population (WORLDBANK 2011).

There have been manifold monetary and non-monetary effects of a transforming society on the move. Among them are the transfers of knowledge and innovation in terms of doing business as well as the big amount of financial and social remittances that guaranteed livelihood for many families. At the same time, we have to take into account social challenges like living with multilocality and family bifurcation.

During the good times, migration was an appropriate tool of social resilience; migrants have been agents of change and development in Albania. Return was a decision taken with a certain amount of freedom. Now, one should distinguish carefully between many cases of forced crisis return (in terms of a „return of failure“, 
CERASE 1974) or return migration in a post-transitional perspective, following the IOM projection of 2005. This pre-crisis study referred to the savings of Albanians living in Greece of estimated two billion Euros (ZwAGER et al. 2005 pp. IV and 61ff.), which have been partly transferred to Albania and invested or spent there. Recently, a certain number of migrants had not enough time abroad for capital accumulation at an amount that is necessary for another restart, now in the country of origin. The problematic situation of many Albanian migrants with permanent existential threats seems to be prevalent. In this respect, return migration is not a panacea and nothing more than a strategy with limited potential for a sustainable solution. Since a couple of years, the situation is reverse: migrants leave a fundamentally altered host society and, at the same time, they encounter more or less unchanged economic, political and social conditions in Albania.

Other problems for migration in general and for individual migrants are continuing over a long period as well. These general hints are persistent before and during the economic downturn. Among them are the insufficient remigration policy of the state (such as a helpdesk for returnees and re-integration), few experiences of returnees with entrepreneurship (following the trial-and-error-principle with sub-optimal success) and a lot of open questions regarding re-integration, mainly for returned long-term emigrants as well as a side-effect of earlier tied migrations. Maybe the biggest problem of return to Albania in terms of the 'social bomb' is the perspective for youngsters. In the future, the question of other options arises, such as the 'second return' (in the case of Greece this is currently not an option), or 'further migration'. Many of the returnees take this possibility into account and are just waiting for the next window of opportunity: according to INSTAT just around $40 \%$ of returnees conceive their return as permanent (INSTAT 2014b, p. 54).

Our initial question, whether Greek-Albanian return migration in the current framework can in general be regarded as a resource, should be put into this perspective. Of course, for some individuals it seems to be, apart from all problems, more than just an option. In general, however, it would have to be denied based on the results presented.

\section{$5 \quad$ Migration and space - A transregional perspective?}

The analysis of different phases and phenomena of Albanian migration has repeatedly pointed to a high degree of spatial differentiation. The sequence of migration and return, for example, is increasing regional polarisation in Albania. Transnationalism in this case includes more than just an interconnection between societies and systems defined by nation states, because individual strategies and social resiliencies are developing highly differentiated extensions below this level. The spatial variety of mobility, which was observed in most migration biographies of the study, can be traced 
only imperfectly in the transnational framework; this concept seems incomplete at that point (see also KING et al. 2013, p. 136).

In this regard, the proposal is to reduce the analytical scale in order to meet the full range of migration networks on the national and subnational level from both perspectives of sending and receiving countries. As already formulated (GöLER \& KRISJANE 2013), broadening the concept of transnationalism with a new transregional perspective seems to be a necessity to strengthen the spatial issue in migration studies (Fig. 3).

This is related to a bundle of challenges. One is the question of multilocality and related networks in- and outside the home country. Another is the sometimes rapidly changing character of migration patterns beside destinations and decision making due to internal and external factors. Transnationality, transregionalism, and multilocality create a medium of socio-spatial simultaneity and diversity, which is hard to analyse. Consecutive return, split return and possible second return are just new elements of resilience in an ageless topic in permanent flux.

Figure 3: From international to transnational to transregional migration (by the author based on GANs 2011, p. 118)

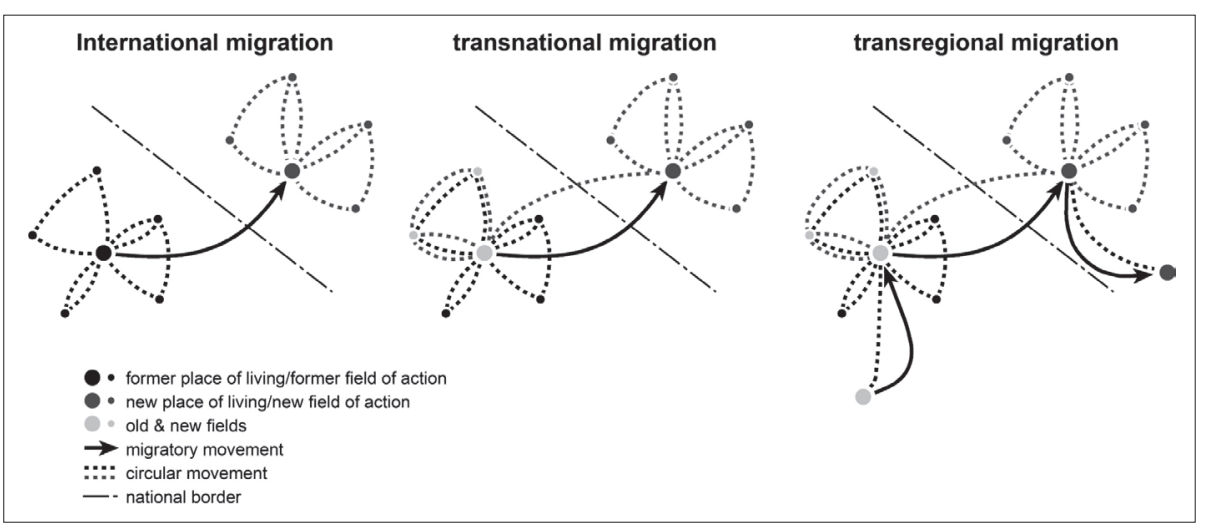

These findings on the case of Albania indicate the general ability of migration systems and subsystems to cope with internally and externally caused shocks and to re-organise in this process in a novel and creative manner. If necessary, migrants define themselves as a new social system. Main characteristics of this system are a widespread multilocal social network led by migration, different individual migration experiences, and migration culture. Migrants are in this sense interpreted as agents of societal transformations, which are able to adapt social practices from different economic, social and cultural contexts. Such kind of resilience as a performed social practice is based on creativity, knowledge and any other individual and personal skills and capacities of these participating in the network. 


\section{References}

Albanian Centre for Competitiveness and International Trade (ACIT) (ed.) (2012), Study on the Economic Impact of the Greek Crisis in Albania. Tirana.

BARJABA K. (2000), Contemporary patterns in Albanian emigration. In: South-East Europe Review for Labour and Social Affairs, 3, pp. 57-64.

BARJABA K., King R. (2005), Introducing and theorising Albanian migration. In: King R., Mai N., Schwandner-Sievers S. (ed.), The new Albanian migration, pp. 1-28. Portland, Sussex, Academic Press.

Carling J., Erdal M.B. (2014), Return Migration and Transnationalism: How Are the Two Connected? In: International Migration, 52, 6, pp. 2-12.

Cassarino J.-P. (2004), Theorising Return Migration: The Conceptual Approach to Return Migrants Revisited. In: International Journal of Multicultural Societies, 6, 2, pp. 253279.

Castles S., Miller M.J. (2009), The Age of Migration. International Population Movements in the Modern World. $4^{\text {th }}$ edition, New York - London, The Guilford Press.

CERASE F.P. (1974), Expectations and reality: A case study of return migration from the United States to the Southern Italy. In: International Migration Review, 8, pp. 245-262.

Dahinden J. (2009), Die transnationale Perspektive. In: terra cognita, 15, pp. 16-19.

Draçı B., BICKerT M. (2013), Albanian return-migration from Greece. The challenges of entrepreneurship and social re-integration as a result of the recent economic crisis. In: Kërkime Gjeografike, 15, pp. 133-148.

Düvell F. (2009), Migration, Minorities and Marginality: New Directions in Europe Migration Research. In: RuMFord C. (ed.), The SAGE Handbook of European Migration Research, pp. 328-348. London.

FAIST T. (2008), Migrants as transnational development agents: an inquiry into the newest round of the migration-development nexus. In: Population, Space and Place, 14, pp. 21-42.

Faist T., Fauser M., Reisenauer E. (2013), Preface and Acknowledgements. In: Faist T., Fauser M., Reisenauer E. (eds.), Transnational Migration, pp. vii-ix. Cambridge, Polity Press.

Gamlen A. (2014), The new migration-and-development pessimism. In: Progress in Human Geography, 38, pp. 581-597.

Gans P. (2011), Bevölkerung. Darmstadt, Wissenschaftliche Buchgesellschaft.

GEDESHI I., ZwAGER N.D. (2012), Effects of the global crisis on migration and remittances in Albania. In: SiRKeCI I., Cohen J.H., Ratha D. (eds.), Migration and Remittances during the Global Financial Crisis and Beyond, pp. 237-254, Washington, The World Bank.

GuonçA A. (2002), Albanische Emigration in den neunziger Jahren - eine neue Ära in der demographischen Entwicklung. In: Kaser K., Pichler R., Schwandner-Sievers S. (eds.), Die weite Welt und das Dorf. Albanische Emigration am Ende des 20. Jahrhunderts, pp. 15-38. Wien, Böhlau.

Glick Schiller N., Basch L.G., Blanc-Szanton C. (1992), Towards a Transnational Perspective on Migration: Race, Class, Ethnicity, and Nationalism Reconsidered. New York, New York Academy of Sciences.

Glick Schiller N., Faist T. (eds.) (2010), Migration, Development and Transnationalization. A Critical Stance (= Critical Interventions: A Forum for Social Analysis, 12). New York Oxford, Berghahn Books. 
GÖLER D. (2007), Entrepreneurship im Transformationskontext - Eine Analyse des regionalen Gründungsgeschehens in Südosteuropa (mit Beispielen aus Albanien und Serbien). In: Europa Regional, 15, pp. 23-37.

GöLER D. (2009), Regionale und lokale Auswirkungen von Migration in Albanien. In: Südosteuropa, 57, 4, pp. 472-499.

GöLER D. (2011), Returnee's Business in Südosteuropa: Remigration als Entwicklungspotential in Albanien? In: Brunnbauer U., NovinscaK K., Voss C. (eds.), Gesellschaften in Bewegung. Emigration aus und Immigration nach Südosteuropa in Vergangenheit und Gegenwart, pp. 205-218. München - Berlin, Sagner.

GöLER D. (2012), Unternehmensgründungen und Entrepreneurship in den westlichen Balkanländern. Fallstudien aus Albanien, Bosnien-Herzegowina und Serbien. In: HumEAU J.-B., Long M. (eds.), Inventer de nouveaux territoires. Comparaisons européenne, pp. 322-349. Angers, Presses de l'Université d'Angers.

GöLER D. (2014), Rückkehr nach Albanien. Migration in Zeiten der Krise. In: SüdosteuropaMitteilungen, 54, 2, pp. 74-87.

Göler D., DoKa D. (2014), Should I stay or should I go? Out-migration, return-migration and development in Albania - The migration-development-nexus at a dangerous crossroads. In: Pichler R. (ed.), Legacy and Change. Albanian transformation from multidisciplinary perspectives (= Studies on South East Europe, 15), pp. 69-80. Wien, LIT.

Göler D., Krisjane Z. (2013), Anmerkungen zur Variabilität von Migrationssystemen (mit Erfahrungen aus Lettland und Albanien). Transnationalismus oder Transregionalismus? In: Mitteilungen der Österreichischen Geographischen Gesellschaft, 155, pp. 125-147.

Göler D. (with contributions by Becker H., BerXholi A., Doka D., Draçi B., Friemer M., StandL H.) (2005), European Shrinking Regions: Applied Regional Geography in Peripheral Areas (with Case Studies from Albania and Germany) (= Studime Gjeografike/ Geographical Studies, 16). Tirana, Qendra e Studimeve Gjeografike.

HaAs H. D. (2008), The Complex Role of Migration in Shifting Rural Livelihoods: A Moroccan Case Study. In: Van Naerssen T., Spaan E., Zoomers A. (eds.), Global Migration and Development, pp. 21-42. New York, Routledge.

HaAs H. D. (2010), Migration and Development: A Theoretical Perspective. In: International Migration Review, 44, 1, pp. 227-264.

Instituti i Statistikave (INSTAT) (ed.) (2009), Shqipëria në Shifra/Albania in Figures 2010. Tirana.

Instituti i Statistikave (INSTAT) (ed.) (2014a), Migration in Albania. Tirana.

Instituti i Statistikave (INSTAT), IOM Tirana (ed.) (2014b), Return Migration and Reintegration in Albania $2013<\mathrm{http} / /$ www.instat.gov.al/media/255982/return_migration and_reintegration_in_albania_2013_.pdf; 4.3.2015>

Iosifides T. (1997), Immigrants in the Albanian Labour Market: A Comparative Survey of Albanians, Egyptians and Filipinos. In: King R., Black R. (eds.), Southern Europe and the New Immigrations, pp. 26-50. Brighton, Sussex Academic Press.

KaPuR D. (2004), Remittances: The New Development Mantra? (= G-24 Discussion Paper Series, 29). New York - Geneva, UN.

Khagram S., Levitt P. (eds.) (2008), The Transnational Studies Reader. New York - London, Routledge.

Kilic T., Calogero C., Davis B., Zezza A. (eds.) (2009), Investing back home. Return migration and business ownership in Albania. In: Economics of Transition 17, pp. 587-623. 
KING R. (2005), Albania as a laboratory for the study of migration and development. In: Journal of Southern Europe and the Balkans, 7, 2, pp. 133-155.

King R., Skeldon R., Vullnetari J. (eds.) (2008), Internal and International Migration - Bridging the Theoretical Divide (= Working Paper, 52). University of Sussex, Sussex Centre for Migration Research.

KInG R., Skeldon R. (2010), 'Mind the Gap!' Integrating Approaches to Internal and International Migration. In: Journal of Ethnic and Migration Studies, 36, 10, pp. 1619-1646.

King R., Povrzanović M., Vullnetari J. (2013), Migration, transnationalism and development on the Southeastern flank of Europe. In: Southeast European and Black Sea Studies, 13, 2, pp. 125-140.

LichtenBerger E. (1976), Albanien - Der isolierte Staat. In: Mitteilungen der Österreichischen Geographischen Gesellschaft, 118, 1, pp. 109-136.

MAI N. (2011), Reluctant circularities: the interplay between integration, return and circular migration within the Albanian migration to Italy (METOIKOS-Project). London.

Marcus G. (1995), Ethnography in/of World System: The Emergence of Multi-sited Ethnography. In: Annual Review of Anthropology, 24, pp. 95-117.

Müller D., Munroe D.K. (2008), Changing rural landscapes in Albania: Cropland abandonment and forest clearing in the postsocialist transition. In: Annals of the Association of American Geographers, 98, 4, pp. 855-876.

Nyberg-Sørensen N., Van Hear N., Engberg-Pedersen P. (2002), The Migration-Development Nexus: Evidence and Policy Options. In: International Migration, 40, 5, 2, pp. 49-73.

Pries L. (ed.) (1999), Migration and Transnational Social Spaces. Aldershot, Ashgate.

SchmidT F. (2003), Politische Transformation in Albanien. In: Jordan P. et al. (eds.), Albanien. Geographie - Historische Anthropologie - Geschichte - Kultur - Postkommunistische Transformation (= Österreichische Osthefte, Sonderband 17), pp. 315-328. Wien, Lang.

Vertovec S. (2009), Transnationalism. London - New York, Routledge.

Vullnetari J. (2007), Albanian Migration and Development: State of the Art Review (= IMISCOE Working Paper, 18). Tirana, Centre for Economic and Social Studies; University of Sussex, Sussex Centre for Migration Research.

Vullnetari J. (2012), Albania on the move. Links between internal and international migration. Amsterdam, Amsterdam University Press.

Vullnetari J. (2014), Internal migration in Albania: a critical overview. In: Pichler R. (ed.), Legacy and Change. Albanian transformation from multidisciplinary perspectives (= Studies on South East Europe, 15), pp. 47-67. Wien, LIT.

VUllnetari J., King R. (2008), 'Does your granny eat grass?' On mass migration, care drain and the fate of older people in rural Albania. In: Global Networks, 8, 2, pp. 139-171.

Williams A.M., BalÁž V. (2015), Migration, Risk and Uncertainty (= Routledge Studies in Human Geography, 53). New York - London, Routledge.

WORLDBANK (ed.) (2011), Migration and Remittances Factbook 2011. Washington.

Zwager N.D., Gedeshi I., Germenji E., Nikas C. (2005), Competing for Remittances. Tirana, IOM. 